Historic, Archive Document

Do not assume content reflects current scientific knowledge, policies, or practices. 



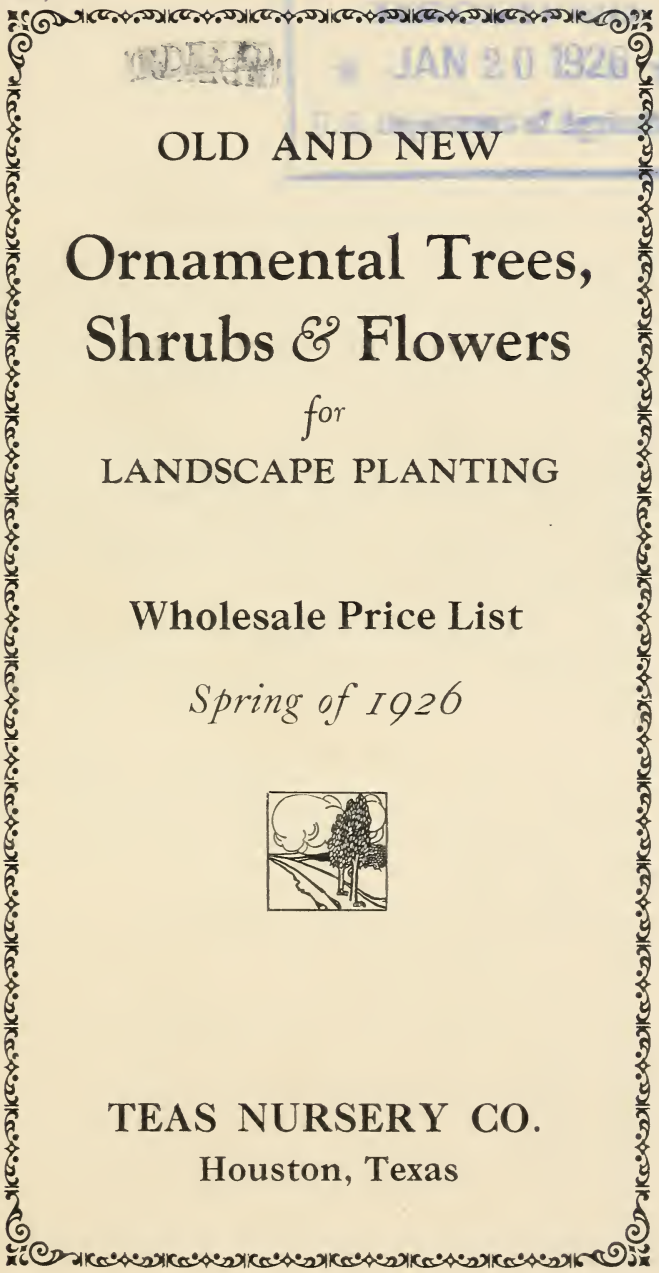




\section{Terms and Conditions}

Terms cash or satisfactory reference before shipping. All sales made and accounts payable in Houston, Texas. Packing carefully done. Materials and labor will be charged at cost in addition to prices given.

We are not liable for injury to stock from frost, hail, fire or unavoidable causes and book all orders accordingly and our responsibility ceases upon delivery in good order to the Railroad or Forwarding Company. Claims, if any, must be made immediately on receipt of stock.

Please give complete shipping directions, Express or Freight and the route. Where no instructions are given we will use our best judgment in forwarding orders.

Non-Warranty. While we guarantee all stock to be true to name, carefully packed and shipped according to instructions, our liability is limited under all circumstances to the amount of the original purchase price received.

Certificate of Inspection accompanies all Shipments. 


\section{Hardy Flowering Shrubs and Plants}

Items Marked B\&B Dug with Ball of Earth and Burlapped

ABELIA, grandiflora.

Per 10 Per 100

1 to 2 feet, well branched

2 to 3 feet, well branched

7.50

ALTHEA-Rose of Sharon,

1 to 2 feet, single, mixed colors.

2 to 3 feet, double and single.

CALLICARPA,

Americana, 2 feet

Purpurea, Chinese,

12 to 18 inches, very bushy.

CAPE JASMINE, gardenia,

18 to 24 inches, bushy...

2 to 3 feet.

Radicans, Dwarf, very beautiful low spreading shrub, field grown, about 1 foot high by 2 feet spread.

CARAGANA, arborea

2 to 3 feet.

COLUTEA, arborescens

3 to 4 feet

4 to 5 feet

COTONEASTER, pannosa

3 to 4 feet, B\&B.

4 to 5 feet, B\&B. 15.00

CRATAEGUS, pyracantha (see pyracantha),

CRAPEMYRTLE, Mixed Colors, mostly pink, well branched,

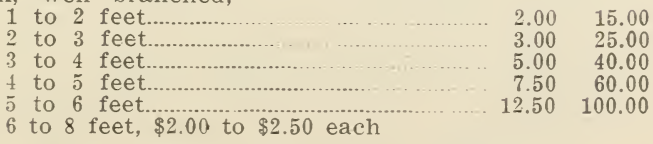

Dwarf Blue, very scarce,

1 to 2 feet.

2 to 3 feet 


\section{Shrubs and Plants-Continued}

Per 10 F'er 100

Dwarf Red, deep rosy crimson, darkest shade, blooms first year,

3 to 4 feet.

4 to 5 feet.

$6.00 \quad 50.00$

$7.50 \quad 60.00$

Imperial Pink, large brilliant deep rosepink flowers, upright growing, very superior, well branched,

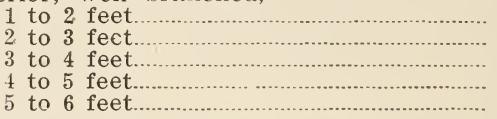

Lilac, a very superior, free blooming variety with large panicles of pure lilac color, strong vigorous grower, very bushy,

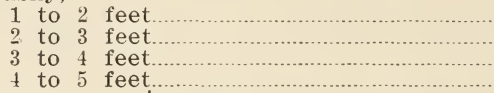

White, 3 to 4 feet.

$8.00 \quad 75.00$

Speciosa, or flos reginae, Queen Crapemyrtle, very large flowers, $\$ 1.50$ each.

CUPHEA, hyssopifolia,

4 -inch pots

5 -inch pots

CYDONIA, japonica, red flowering Japan quince, 2 years.

DECODON, verticallatus (may be Malpighia glabra),

$21 / 2$-inch pots

Field grown, 12 to 18 inches, B\&B

DURANTA, plumari,

3 -inch pots, strong:

EHRETIA, elliptica, very beautiful native large shrub or small tree, bushy specimens,

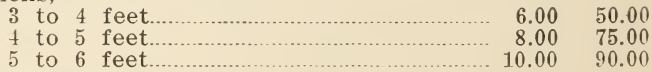

Tree Form, trained,

5 to 6 feet. 


\section{Shrubs and Plants-Continued}

Per 10 Per 100

ERYTHRINA, crista galli,

Pot grown

ESCALLONIA, montevidensis,

1 to 2 feet, B\&B.

EUGENIA, hookeriana,

3 -inch pots

6 -inch pots

Larger sizes on application.

EUONYMUS, japonica,

12 to 18 inches.

18 to 24 inches

Patens, 2-year field grown,

12 to 18 inches.

35.00

FEIJOA, sellowiana. pineapple guava, fine new evergreen shrub, field grown, well branched,

8 to 12 inches, $\mathrm{B} \& \mathrm{~B}$

4.00

850

12 to 18 inches, $\mathrm{B} \& \mathrm{~B}$

12.00

18 to 24 inches, $\mathrm{B} \& \mathrm{~B}$

15.00

35.00

75.00

2 feet to $21 / 2$ feet, $B \& B$ 100.00

GARDENIA, grandiflora (see Cape Jasmine),

HIBISCUS, moscheutos, hardy Hibiscus, mixed colors, pink and white, strong blooming size

HOLLY, deciduous, ilex decidua, brilliant scarlet berries all winter, strong transplanted,

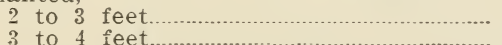

JASMINE, floridum, everblooming, 2-year field grown, B\&B.................................. 1000 Primulinum, $2 \frac{1}{2}$-inch pots, fine plants... 2.00 Sambac-arabian, 4-inch pots................... 4.00

Grand Duke of Tuscany, strong,

3 -inch

4 -inch

3.00

4.00

Maid of Orleans, strong plants,

3 -inch

4-inch 


\section{Shrubs and Plants-Continued}

Per 10 Per 100

LIGUSTRUM, sinense, commonly known as Amoor River South, finest of all evergreen hedge plants for the Southern States,

1 year, 1 to 2 feet.

2 year, 2 to 3 feet, transplanted, well branched

3 to 4 feet, well branched

4 to 5 feet, well branched

5 to 6 feet, well branched

2.00

15.00

$3.00 \quad 20.00$

$4.00 \quad 30.00$

Large selected specimen plants, $\$ 1.00$ each and up.

Sinensis nana, a handsome dwarf compact growing form, valuable in landscape, planting,

2 to 3 feet

3 to 4 feet

7.50

40.00

Large selected specimen bushes, $\$ 1.00$ each and up.

LIGUSTRUM, sinensis pendula, new, our own introduction, branches drooping, very handsome, 2-year,

2 to 3 feet.

3 to 4 feet 60.00

LIGUSTRUM, japonicum, large glossy evergreen foliage, finest of all quick growing evergreen shrubs,

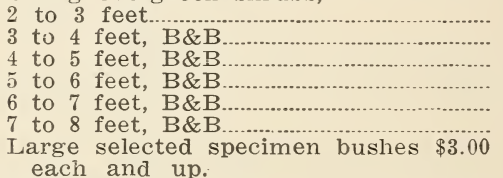

Nepalense or compact, wax leaved (also called Griffing's wax), finest of all Ligustrums, large very dark green glossy foliage, showy panicles of white flowers in spring. One of the choicest of all Southern shrubs,

1 year from $2 \frac{1}{2}$-inch pots.

2 year field grown, well branched, 1 to $11 / 2$ feet, B\&B.

$11 / 2$ to 2 feet, well branched, $\mathrm{B} \& \mathrm{~B}$

$1 \frac{1}{2}$ to 2 feet, extra heavy bushy B\&B

2 to $2 \frac{1}{2}$ feet, well branched, B\&B..... $21 / 2$ to 3 feet, well branched, B\&B... 3 to $3 \frac{1}{2}$ feet, well branched, B\&B...... 30.00 


\section{Shrubs and Plants-Continued}

Per 10 Per 100

LOQUAT or Japanese Plum, handsome broad leaved evergreen, edible fruit, 2 -inch pots

$11 / 2$ to 2 feet, field grown, B\&B

2 to $21 / 2$ feet, field grown, $B \& B$

$21 / 2$ to 3 feet, field grown, B\&B 20.00

MAGNOLIA (see trees)

MET'ROSIDEROS, floribunda, bottle

brush, $2 \frac{1}{2}$-inch pots.

MYRTUS, communis, Sweet or German Myrtle, field grown, about 1 foot bushy, $\mathrm{B} \& \mathrm{~B}$

OLEANDER, extra strong, 3-year very bushy blooming size,

Double pink and double white and mixed colors, 2 to 3 feet.

Double pink and double white and mixed colors, 3 to 4 feet

Double pink and double white and mixed colors, 4 to 5 feet.

Variegated Leaved, double pink flowers, 2 to 3 feet

3 to 4 feet.

For $B \& B$ add $10 \mathrm{c}$ each to prices noted.

PHOTINIA, dentata,

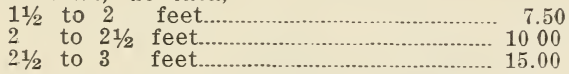

PITTOSPORUM, tobira, 5000 strong plants in stock, one of the finest of Southern evergreen shrubs,

$2^{1} / 2$-inch pots, well rooted

3 -inch pots, well rooted

Field Grown, stocky,

8 to 10 inches, B\&B

10 to 12 inches, $B \& B$

12 to 15 inches, $B \& B$

15 to 18 inches, B\&B

Variegated,

3 -inch pots

4-inch pots 


\section{Shrubs and Plants-Continued}

Per 10 Per 100

PLUMBAGO, capensis, 4-inch pots

POMEGRANATE (punica), double red, variegated and white flowering,

2 to 3 feet, well branched........................ 2.50 20.00

3 to 4 feet

$4.00 \quad 35.00$

4 to 5 feet

$6.00 \quad 50.00$

5 to 6 feet, very heavy.

Fruit Bearing, very strong, bushy plants,

2 to 3 feet.

3 to 4 feet

PYRACANTHA, Angustifolia, heavy,

2 to 3 feet, $B \& B$.

3 to 4 feet, $B \& B$

80.00

4 to 5 feet, B\&B

$15.00 \quad 100.00$

Crenulata, heavy branched,

2 to 3 feet, $B \& B$

7.50
60.00

3 to 4 feet, $B \& B$

4 to 5 feet, $B \& B$

125.00

Yunnanense, very bushy,

2 to 3 feet spread, B\&B

3 to 4 feet spread, B\&B

4 to 5 feet spread, B\&B

20.00

150.00

QUINCE, Fruit Bearing,

2 to 3 feet.

Flowering (see cydonia).

SPARTIUM, junceum

3.00

SYMPHOROCARPUS, vulgaris,

Snowberry, Indian Currant,

2 years

VITEX, agnus castus, Chaste Tree or Lavender Shrub of the South, hardy, easily grown and useful; should be in every garden, 2-year, field grown,

2 to 3 feet.

3 to 4 feet.

Incisa, smaller growing, constant bloomer, graceful shrub,

2 to 3 feet.

3 to 4 feet

WILD PEACH OR CHERRY LAUREL,

$11 / 2$ to 2 feet, $B \& B$.

2 to 3 feet, B\&B.

3 to 4 feet, $B \& B$ 


\section{Trees}

Per 10 Per 100

ASH, Arizona,

5 to 6 feet

6 to 7 feet................................................... 7.50

Biltmore, 7 to 8 feet.................................. 10.00

CAMPHOR, 1 year seedlings,

6 to 12 inches.

CATALPA, speciosa,

6 to 8 feet

CITRUS, trifoliata,

1 to 2 feet

2 to 3 feet

CYPRESS, deciduous,

1 to 2 feet, 1 year.

3 to 4 feet

4 to 5 feet

EHRETIA, elliptica, beautiful native tree, nearly evergreen, white flowers followed by showy yellow berries. Endures the most severe drouth and has very beautiful dense dark green foliage, low branched,

3 to 4 feet.

4 to 5 feet

5 to 6 feet

10.00

90.00

Standard or Tree Form, 5 to 6 feet...

ELM, American White, the Academic or Large Leaved Elm,

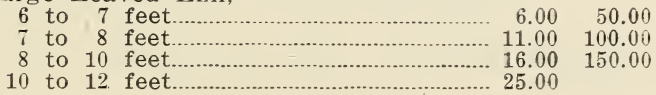

Cork Barked, Small Leaved Elm,

á to 6 feet.................................................... 50.00

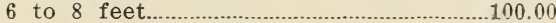

EUCALYPTUS, pot grown, 3 to 4 feet.

GRAVILLEA, robusta, Australian Silk Oak, pot grown,

3 -inch, $1 \frac{1}{2}$ to 2 feet

4 -inch, 2 to 3 feet 


\section{Trees-Continued}

Per 10 Per 100

HOLLY, ilex decidua, Deciduous Holly, very showy red berries in winter, fine transplanted, stocky,

2 to 3 feet.

3 to 4 feet.

KOLREUTERIA, paniculata,

2 to 3 feet.

LOQUAT (see Shrubs).

MAGNOLIA, grandiflora, Southern Evergreen Magnolia, fine very white fragrant flowers, transplanted,

2 to 3 feet, B\&B.................................... 10.00

3 to 4 feet, B\&B........................................ 20.00

4 to 5 feet, B\&B........................................ 35.00

MIMOSA, very beautiful fern-like foliage, fragrant pink flowers in spring,

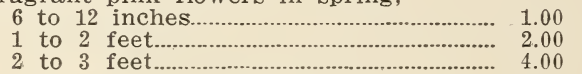

PARKINSONIA, aculeata, retama, fine feathery foliage, yellow pea-shaped flowers throughout the summer,

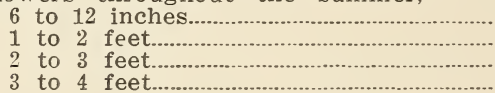

POPLAR, lombardy, upright form,

6 to 7 feet

7 to 8 feet.

PRUNUS, caroliniana (Wild Peach), see Shrubs.

STERCULIA, platanifolia,.

1 to 2 feet.

2 to 3 feet.

SYCAMORE, American, extra fine transplanted,

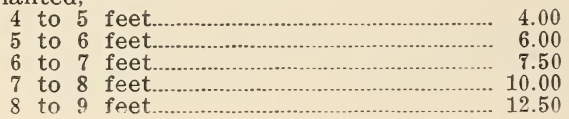




\section{Trees-Continued}

Per 10 Per 100

TALLOW TREE (sapium sebiferum), a valuable new shade tree from China. grows in poorest soils, withstands severest drouths, foliage dense deep green gorgeous autumn colorings,

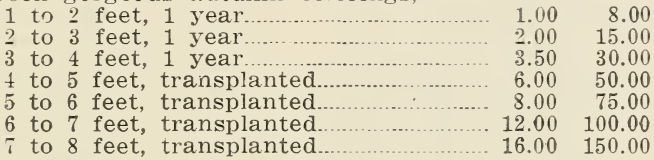

WILD PEACH (see Shrubs).

ZELCOVA, acuminata, new tree from China, resembles the Elm,

4 to j feet, transplanted........................ $6.00 \quad 50.00$

5 to 7 feet, transplanted …….............. $80 \quad 75.00$

\section{Coniferous Evergreens}

\section{All Evergreens B\&B Unless Noted}

ARBOR VITAE, Chinese, selected bushy

Trees, transplanted, well grown,

1 to $11 / 2$ feet

$11 / 2$ to 2 feet, $B \& B$

2 to 3 feet, $B \& B$

2.50

20.00

feet, $B \& B$

4.00

6.00

8.50

4 to 5

feet, $B \& B$

12.50

5 to 6

feet, $B \& B$

15.00

30.00

50.00

75.00

100.00

125.00

Prices quoted on larger sizes up to 10 feet.

Special Type, much more dense in growth, pyramidal form seedlings, uniform in habit of growth,

2 to 3 feet, B\&B.

$12.00 \quad 100.00$

3 to 4 feet, B\&B.

$16.00 \quad 150.00$

Rosedale Hybrid,

8 to 12 inches, $B \& B$

$5.00 \quad 40.00$

12 to 15 inches, $B \& B$

$600 \quad 50.00$

15 to 18 inches, $\mathrm{B} \& \mathrm{~B}$

$\begin{array}{ll}7.50 & 60.00\end{array}$

18 to 24 inches, $B \& B$

$10.00 \quad 80.00$

24 to 30 inches, B\&B

$12.50 \quad 100.00$

Berckmann's Golden,

2 to $21 / 2$ feet, $B \& B$

$21 / 2$ to 3 feet, $B \& B$ 


\section{Coniferous Evergreens-Continued}

Per 10 Per 100

CEDRUS, deodara,

10 to 12 -inch, pot grown

12 to 18 inches, $\mathrm{B} \& \mathrm{~B}$

18 to 24 inches, $B \& B$

CRYPTOMERIA,

12 to 18 inches, $\mathrm{B} \& \mathrm{~B}$

10.00

CYPRESS, Arizona,

12 to 18 inches, $\mathrm{B} \& \mathrm{~B}$

18 to 24 inches, $B \& B$

24 to 30 inches, $B \& B$

7.50

30 to 36 inches, $\mathbf{B} \& \mathrm{~B}$

3 to 4 feet, B\&B

4 to 5 feet, $B \& B$

3000

40.00

Italian, select true upright form,

6 to 8 inches, pot grown

1.10

10.00

8 to 12 inches, $\mathrm{B} \& \mathrm{~B}$

350

25.00

12 to 18 inches, $\mathrm{B} \& \mathrm{~B}$

5.00

40.00

18 to 24 inches, $B \& B$

7.50

60.00

24 to 30 inches, $B \& B$

12.50

100.00

30 to 36 inches, $\mathrm{B} \& \mathrm{~B}$

17.50

150.00

3 to 4 feet, $B \& B$

22.50

4 to 5 feet, $B \& B$

35.00

200.00

5 to 6 feet, $B \& B$

300.00

6 to 7 feet, B\&B

6000

75.00

7 to 8 feet, B\&B, $\$ 10.00$ each.

Horizontalis, very handsome upright evergreen, with picturesque spreading branches,
3 to 4 feet, B\&B
4 to 5 feet, $B \& B$
5 to 6 feet, $\mathrm{B} \& \mathrm{~B}$. 25.00
6 to 7 feet, $B \& B$ 35.00
7 to 8 feet, $B \& B$ 50.00

\section{Vines}

ANTIGONON, leptopus, Coral Vine, Queens Crown, Rosa de Montana, $2 \frac{1}{2}$-inch pot grown, blooming size........

1 year, field grown.

2 year, field grown

BIGNONIA, tweediana or cunningahamiana, Evergreen, Clinging Vine, large yellow flowers, strong plants, 


\section{Vines-Contiuned}

Per 10 Per 100

BOUGAINVILLEA, glabra snaderiana,

$21 / 2$-inch pots

2.50

4-inch pots

4.00

5 -inch pots

7.50

6-inch pots

15.00

Crimson Lake, New Red,

$2 \frac{1}{2}$-inch pots

3.50

Brasiliensis, very large rosy purple,

$21 / 2$-inch

4-inch

3.50

5 -inch

6.00

10.00

Extra large specimen Bougainvilleas, $\$ 3.00$ to $\$ 12.00$ each.

CONFEDERATE Jasmine (rynchospermum jasminoides),

Pot grown

DOLICHOS japonica, Kudzu or Japan Bean Vine,

2 year

EUONYMUS Patens,

$21 / 2$-inch pots

Field grown

FICUS, repens or pumila, Clinging Fig Vine, evergreen, strong plants,

$21 / 2$-inch pots

4 -inch pots

WISTERIA, Chinese,

Field grown

\section{Greenhouse Bedding Plants, Perennials, Etc.}

ASCLEPIAS, curassavica,

Pot grown

ASPARAGUS, plumosus,

$2 \frac{1}{2}$-inch pots

Springeri, 3-inch pots.

COLEUS, in assortment,

3 -inch pots 


\section{Plants and Perennials-Continued}

Per 10 Per 100

COCOLOBA, platyclada,

$2 \frac{1}{2}$-inch pots

CUPHEA, hyssopifolia,

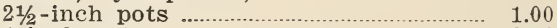

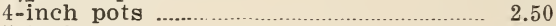

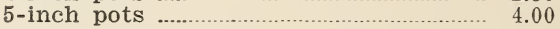

FICUS, nitida,

$2 \frac{1}{2}$-inch pots …….............................. 2.50

4 -inch pots …............................ 5.00

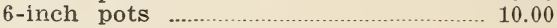

EUPHORBIA, splendens,

4-inch pots

GAILLARDIA, mixed,

Pot grown.

GRAVILLEA (see Shrubs).

HIBISCUS, Chinese,

5 -inch pots

HOYA CARNOSA, Wax Plant,

4-inch pots

JASMINE (see Shrubs)

OPHIOPOGON, jaburane, Dragons Beard. $21 / 2$-inch pots

PANDANUS, veitchii, 4 -inch pot plants.... 5 and 6 inch specimens, $\$ 1.50$ to $\$ 3.00$ each.

POINSETTIAS, pot grown........................... 3.00

POTHOS AUREA, 3-inch...................... 2.00

RUELLIA, mokiana, 3-inch......................... 1.50

SANSEVEIRA, zeylanica, 4-inch pots....... 5.00 Larger, $\$ 1.00$ each.

STROBILANTHUS, Anisophyllus …........... 1.00

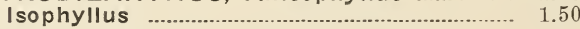

SALVIA, farinacea, hardy blue Salvia....... 1.50

VERBENA, hybrids of erinoides, profuse blooming, our own introduction,

Albion, pure white

Bellaire, new deep purple................................ 1.00

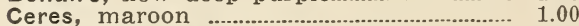

Madge Roberts, deep rose pink ................ 1.00

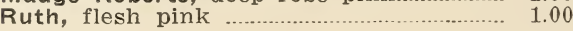




\section{Bamboo Canes and Reeds}

Per 10 Per 100

ARUNDINARIA, falicata, Baby Bamboo, divided clumps

5.00

ARUNDO, donax, Elephant Grass, strong divisions

BAMBUSA, Japanese Bamboo, strong divided clumps

Nitida, very dwarf, fine ground cover.

GYNERIUM, Pampass Grass.

5.00

\section{Palms}

cocos, australis, field grown,

12 to 18 inches, $\mathrm{B} \& \mathrm{~B}$

18 to 24 inches, B\&B.

15.00

2 to 3 feet, B\&B

PHOENIX, canariensis,

$21 / 2$-inch pots

4-inch pots

3.50

Gallon cans ……....................................... 10.00

Field grown, 2 to $21 / 2$ feet, B\&B....... 17.50

Field grown, $21 / 2$ to 3 feet, $B \& B$....... 25.00

WASHINGTONIA, robusta, field grown,

$11 / 2$ to 2 feet, $B \& B$............................ 15.00

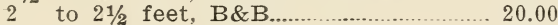

$21 / 2$ to 3 feet, B\&B............................. 25.00

\section{Fruit Trees, Etc.}

FIG, Celestial, or Sugar Fig,

12 to 18 inches.

$3.00 \quad 25.00$

18 to 24 inches.

$4.00 \quad 35.00$

MAGNOLIA, the Standard Commercial

Fig,

12 to 18 inches.

$3.00 \quad 25.00$

18 to 24 inches.

$4.00 \quad 30.00$

$P E A C H$, in best varieties for the South, 4 to 5 feet.

PEARS, in variety,

4 to 5 feet

PLUM, Excelsior,

4 to 5 feet. 
